\title{
Development of Dekstop Based Customer Data Information System (Case Study: PDAM Tirta Fulawan Siemeulue Barat)
}

\author{
Rafi Moerdani * \\ Information Technology Faculty, STMIK Abulyatama Aceh \\ Email: rafimoerdani@gmail.com
}

Received: 19 January 2021; Accepted: 25 March 2021; Published: 1 April 2021

\begin{abstract}
The purpose of this research is to find out and information systems that are running at PDAM Tirta Fulawan, West Simeulue District, and to create an application for customer data management, payment, and meter installation to simplify and speed up the data collection process. From the results of research and observations that have been carried out at PDAM Tirta Fulawan, West Simeulue District, it can be concluded that with this customer information system in PDAM Tirta Fulawan, West Simeulue District, information becomes precise and accurate, especially in the service section, and to obtain information These customers become easier, this information system is able to solve problems that often occur in PDAM Tirta Fulawan, West Simeulue District, namely it is difficult to control and supervise customer data and account payments which can avoid delays in making reports every year and for a certain period, and the creation of a system program information in order to obtain quality information.
\end{abstract}

Index Terms: Information Systems; Customers; PDAM Tirta Fulawan; Desktop-Base.

\section{Introduction}

The development of the world of technology and information systems has grown rapidly and has penetrated the side of human life [1]. Such development is supported by the availability of hardware and software which are getting more and more powerful day by day [2]. Along with the rapid development of technology in the field of information, it has become a basic necessity in the world of business and other businesses and has an impact on all lives [3].

With a system that is already based on computer technology, it is likely that it will be very helpful in processing information data to be faster [4], so that the performance of the company or agency will increase. The information system is a series of normal procedures in which data is collected, processed into information, and distributed to users [5, 6]. So, an information system was developed to help any human activity that requires accurate and easy information in processing data on PDAM customer information. At PDAM Tirta Fulawan, West Simeulue Subdistrict, data management is still found that is carried out conventionally, especially in customer data management. Conventional customer data management is certainly not very effective and efficient because it takes a long time to search for data. Each employee who works at PDAM Tirta Fulawan, West Simeulue Subdistrict, must fill in the number of customers that have been recorded by PDAM Tirta Fulawan, West Simeulue Subdistrict in conventional books, which at any time can be lost or damaged. Then this will complicate the calculation of the number of customers that have been served by employees to calculate the customers that will be processed by these employees. In addition, the absence of customer data reports has resulted in frequent miscalculations of income. And this certainly has an impact on the effectiveness and performance of PDAM Tirta Fulawan, West Simeulue District.

Therefore, to overcome the weaknesses of the customer data collection system at PDAM Tirta Fulawan, West Simeulue Subdistrict, which is still being carried out conventionally, it is necessary to create a computer-based customer data management information system. Wherewith a computer-based system, customer data processing can be done effectively and efficiently. Even though the amount of data that must be entered is relatively large, the accuracy of the report can be achieved as much as possible so that errors in entering and calculating data are relatively unlikely. 


\section{Research Method}

To assist in the preparation of this research, it is necessary to have a clear framework in stages. This framework represents the steps that will be taken in solving the problems to be discussed. The research flowchart used is as shown in Figure 1.

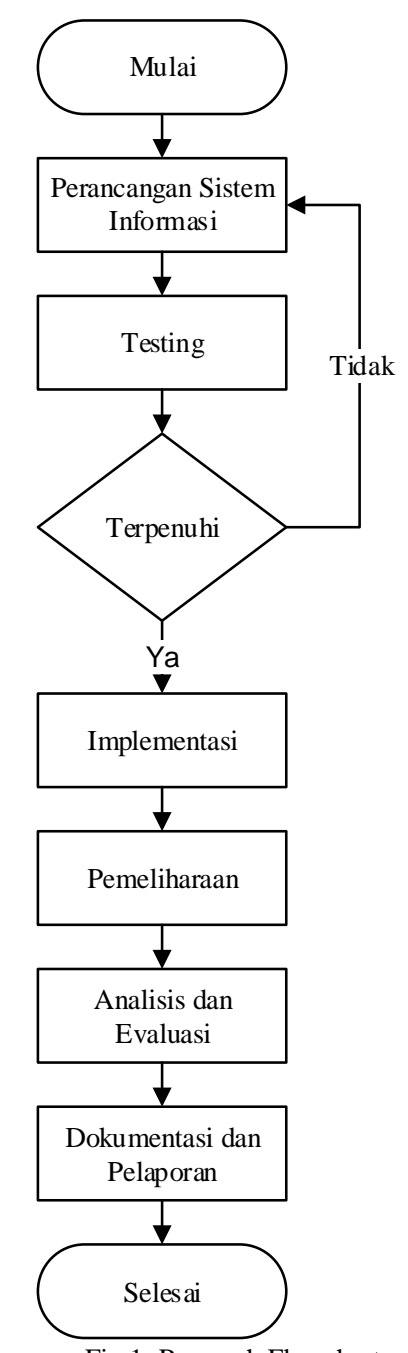

The research flowchart is used to describe the steps taken and the data collection from beginning to end $[2,7]$. The following is an explanation of the process and stages carried out in the research flow diagram. Writing the theoretical basis is done by looking for reference sources for the material in the module discussed and the sources must be reliable, such as books and journals in order to expand knowledge. The theoretical basis is also useful for discussion and analysis.

Problem identification is used to describe the problems contained in the investigation and then the problem is formulated or solved so that the problem can be solved $[8,9]$. The arrangement of the problem is based on the background that has the reasons for conducting the research using the analytical method and its benefits [10, 11]. Problem limitation serves to limit problems related to the material being studied and used related to variance analysis to make it easier to solve problems [12, 13]. Limiting problems are used to limit the number of samples taken and the software used to further process the data that has been obtained [14]. The main objective is the main objective of research that is useful for finding the location of the problem in a case study [15]. How the data works by taking samples from case studies related to the method of analysis [16]. The stage of making a case study is an application according to the method studied [17, 18]. Making a case study with the amount of data that is in accordance with the assumptions contained in the analysis [19, 20], after obtaining the data, a case study must be carried out by comparing the existing data whether the case study is suitable or not with the data that is owned. Re-data collection must be carried out, but if the case study is in accordance with the data held, then the next step is to the data collection stage [21]. The assumptions in the analysis of variance, namely that a population is spread or normally distributed [22, 23], the variance or variance of a population that is tested is the same and the sample is not related to one another (independent) [24, 25].

The data testing stage is the stage of testing data from raw data and then tested to determine the variance and normality of the data [26]. If the data is tested, if it has passed the test [27] and the assumptions are met, it will proceed 
to the data processing stage [28, 29]. Data testing is carried out if the analysis method requires testing, if using a method that does not require testing and assumptions, then proceed to the data processing stage. The data processing stage is the stage of processing data from raw data and then processing it into a data report that can be useful information. Information can produce a conclusion from the research objectives that have been made previously.

The analysis stage is to analyze the results of calculations from data processing that have been done using manuals and software. Comparative analysis functions to analyze the differences and similarities of manual and software calculations. The conclusion is a summary of the answers to the research objectives made. Suggestions are made to provide input or criticism in order to improve future research to make it better.

In writing this research, the author uses several Field Research methods, namely by obtaining data directly from the research site so that the data required in this study are the real data obtained when the research was carried out.

As for the research data collection, the writer uses the following collection methods:

a) Interviews, namely data collection by conducting interviews directly with related parties in order to obtain information on the problems faced

b) Observation, namely direct observation of the current system mechanism in PDAM Tirta Fulawan, Simeulue Regency

\section{Result and Discussion}

The Information System Development at PDAM Tirta Fulawan West Simeulue Subdistrict based on Desktop which the author designed consists of several stages, namely input design, output design, process design, control design, workforce design, and cost design. The writer hopes that this design will make it easier for each user, especially the PDAM Tirta Fulawan service division, West Simeulue District. For more details, the design stages can be seen in the following explanation. The use of a customer data collection information system design at PDAM Tirta Fulawan, West Simeulue Subdistrict, based on a desktop, seen from the design of the application in the form of an application display. The login form is used as system security from access permissions, so that data security can be guaranteed. Here the user is to enter a user name and password to be able to access the next data. For more details, the login process can be seen in the image below.

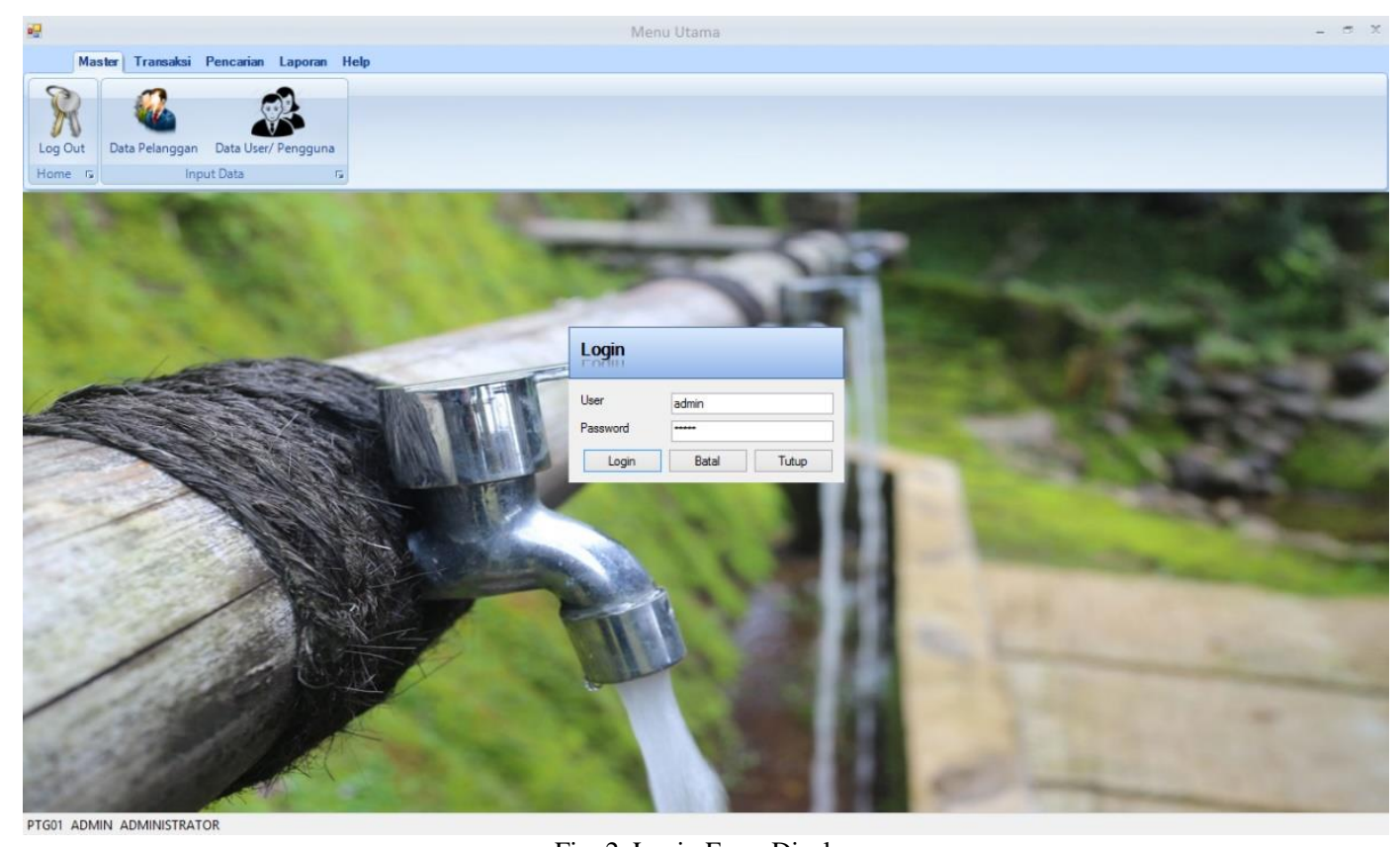

Fig. 2. Login Form Display

The login display form consists of a username and password, and a login button, cancel and close. Behind the login form also index the admin page but cannot be accessed if the login form is still active. If the user name and password are successfully logged in, then the main menu will be directly accessible. In the form below is the main menu form consisting of the master menu, transactions, searches, and reports. The master sub-menu consists of user and customer data. In the family transaction sub-menu, we store installation data, account payments, and account payment accounts. The inspection sub-menu consists of payment details and transaction details. Furthermore, the report sub-menu consists of customer data, account payment details, daily reports, and charts. Computer users just need to click the desired menu icon to see what is in the file. 


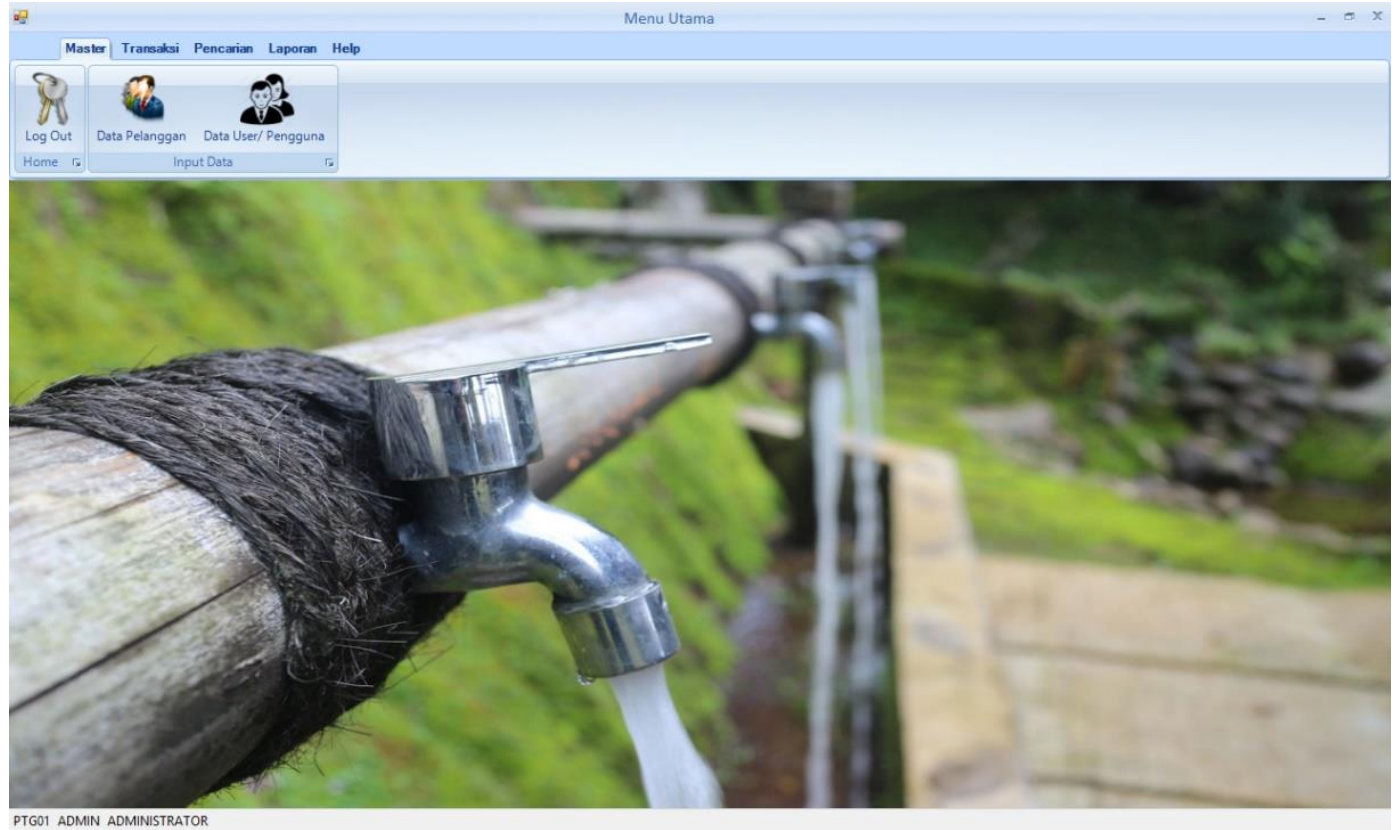

Fig. 3. Main Menu Display

In addition to explaining several menus along with sub-menus from the menu, under the toolbar, the menu also displays user information, namely in the form of code, name, and application user level. The user input menu is a page where the user can input user data which contains the code, name, password, and status. In addition, there are also several buttons such as save, delete, edit and close. Use delete and edit where the user enters the user code and then by clicking the delete or edit button the process will take place according to the use of the button in question.

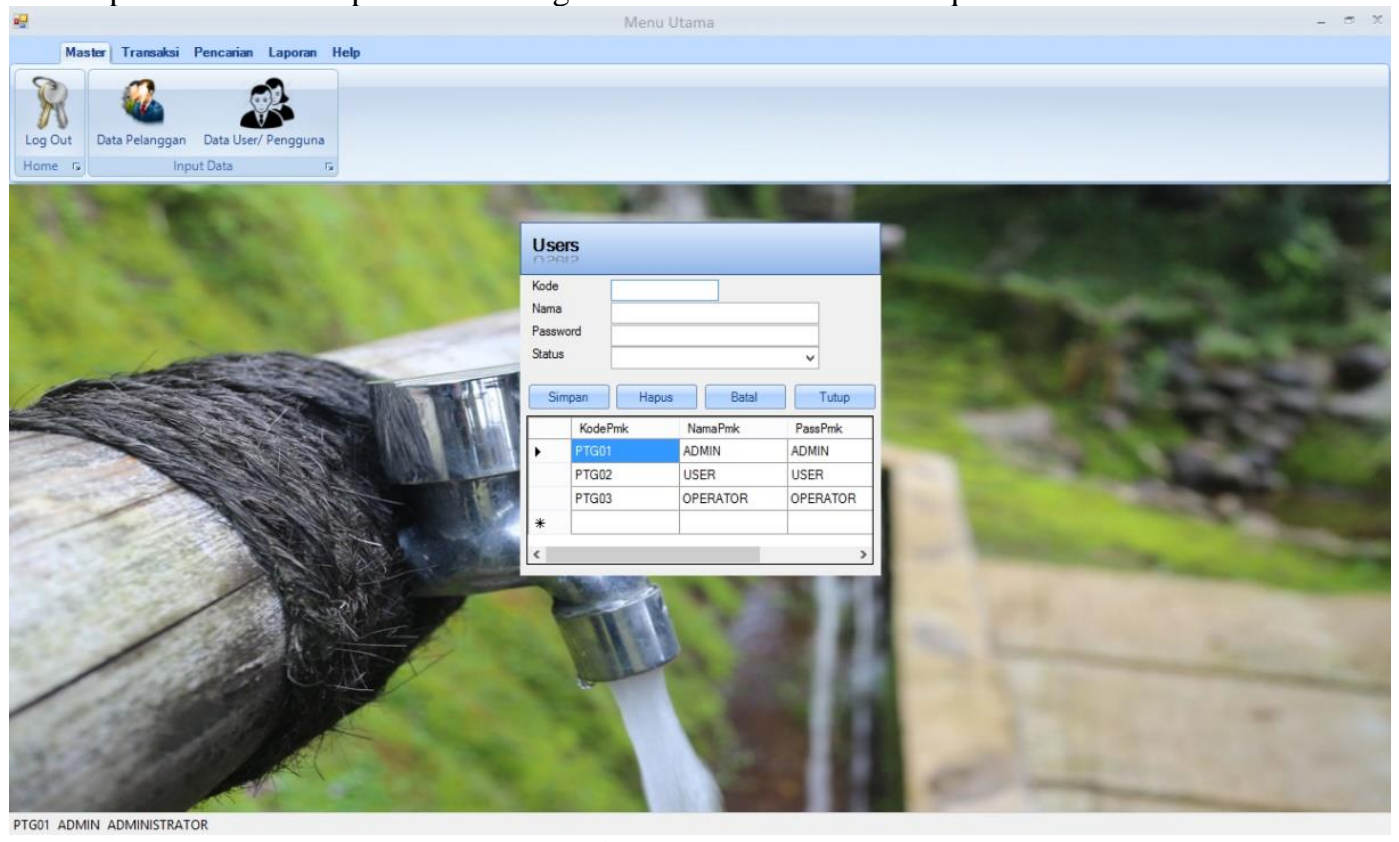

Figure 4. User Input

The customer input menu is a page where users can input customer data. The customer form data consists of registration number, date, full name, address, occupation, a number of occupants, how many water taps, the status of being able to pay for water, serial number, usage, installed by the officer, date of installation, meter brand. And then the buttons provided are also the same on the user form and other forms, namely; save, delete, cancel and close. To display customer data that has been previously inputted, it is also displayed in the list below the button. 


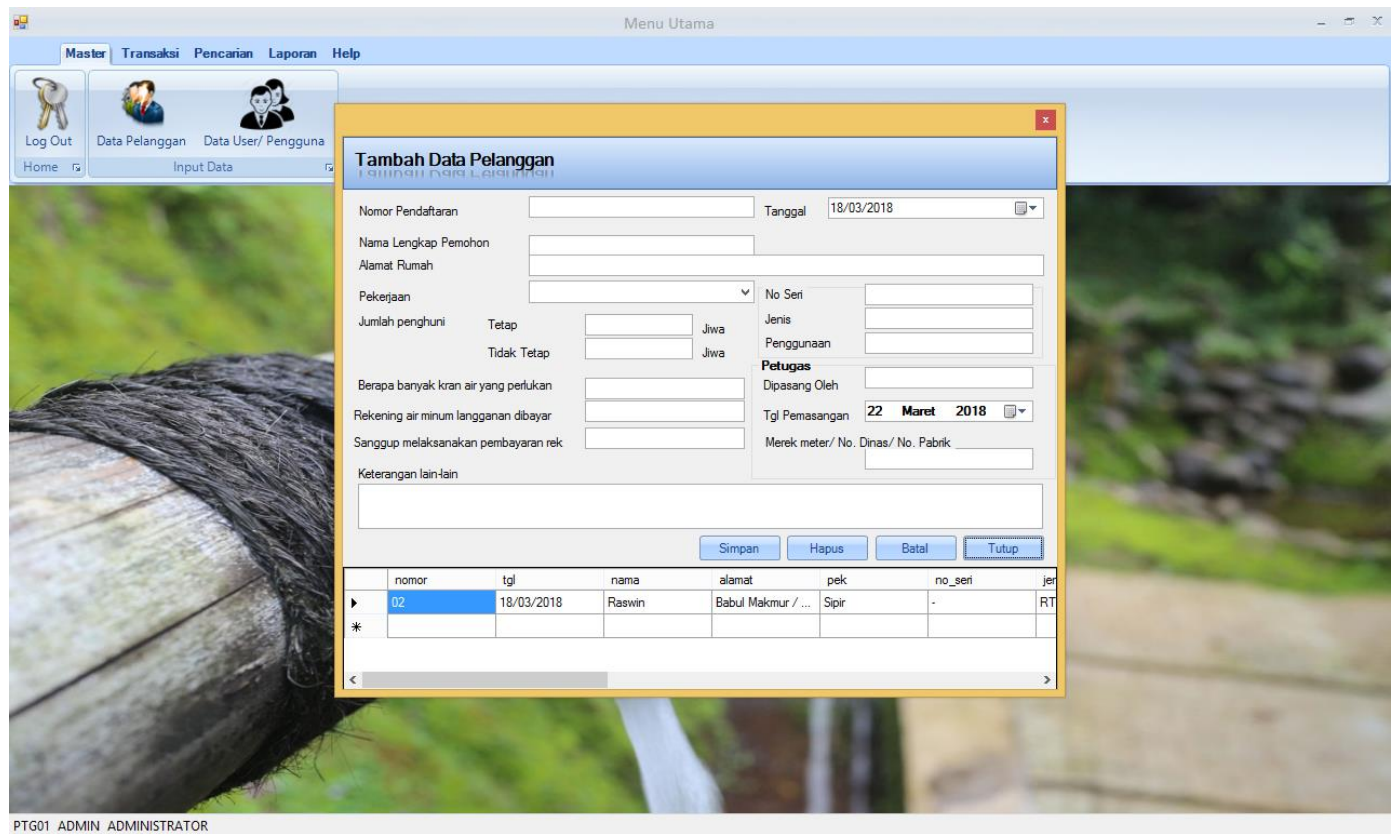

Fig. 5. Customer Input

Payment menu for each meter's account payment transactions based on monthly usage. This form consists of the customer number, customer name, serial number, month's account, address, last stand, current stand, fines, local taxes. Each transaction will generate a proof of payment for an account as shown in Figure 6 below.

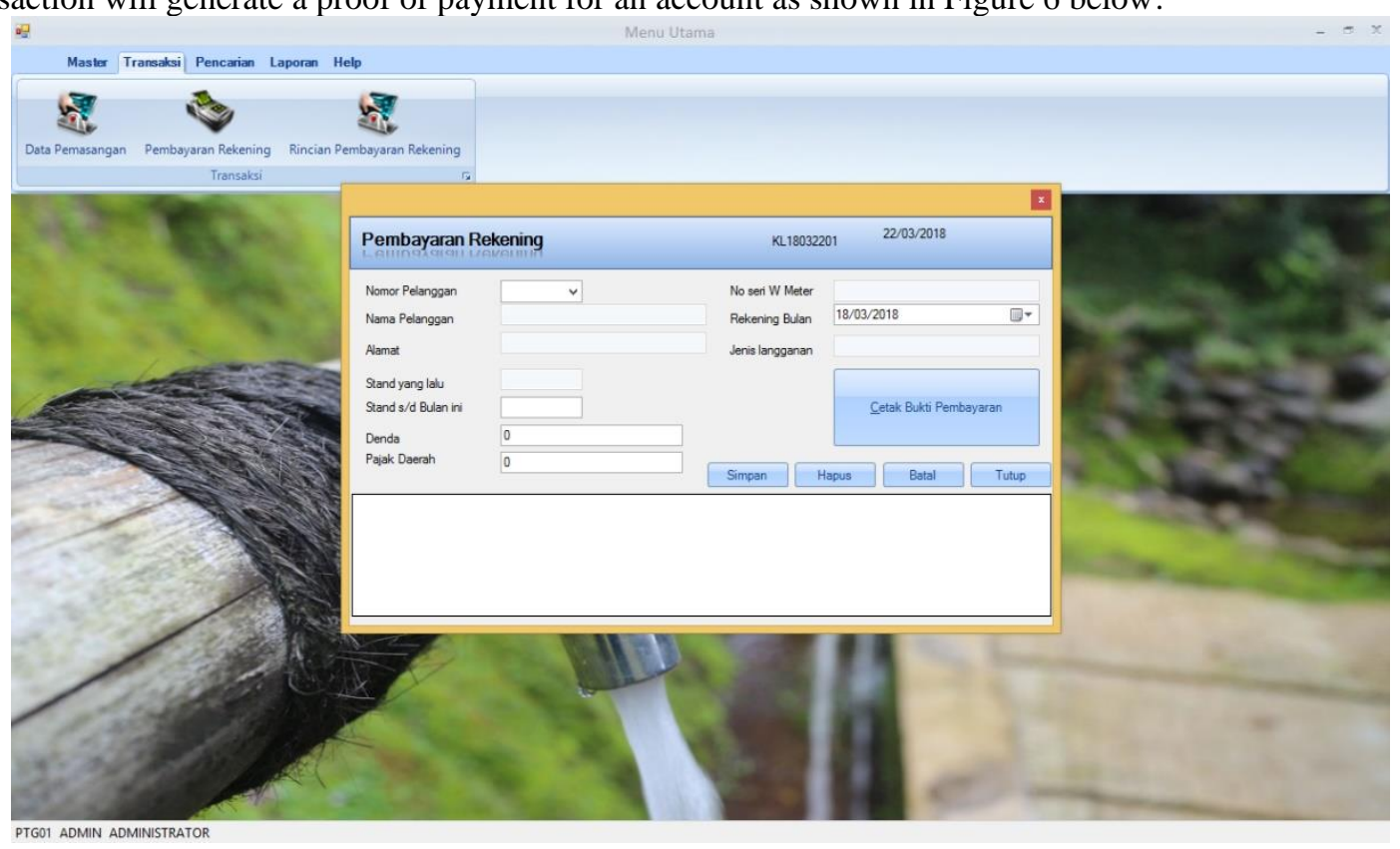

Figure 6. Input Payment Account

The account payment form is a metered account payment process. Which consists of customer number, customer name, address, last stand, current stand, fines, taxes, w meter serial number, month's account, type of subscription. 


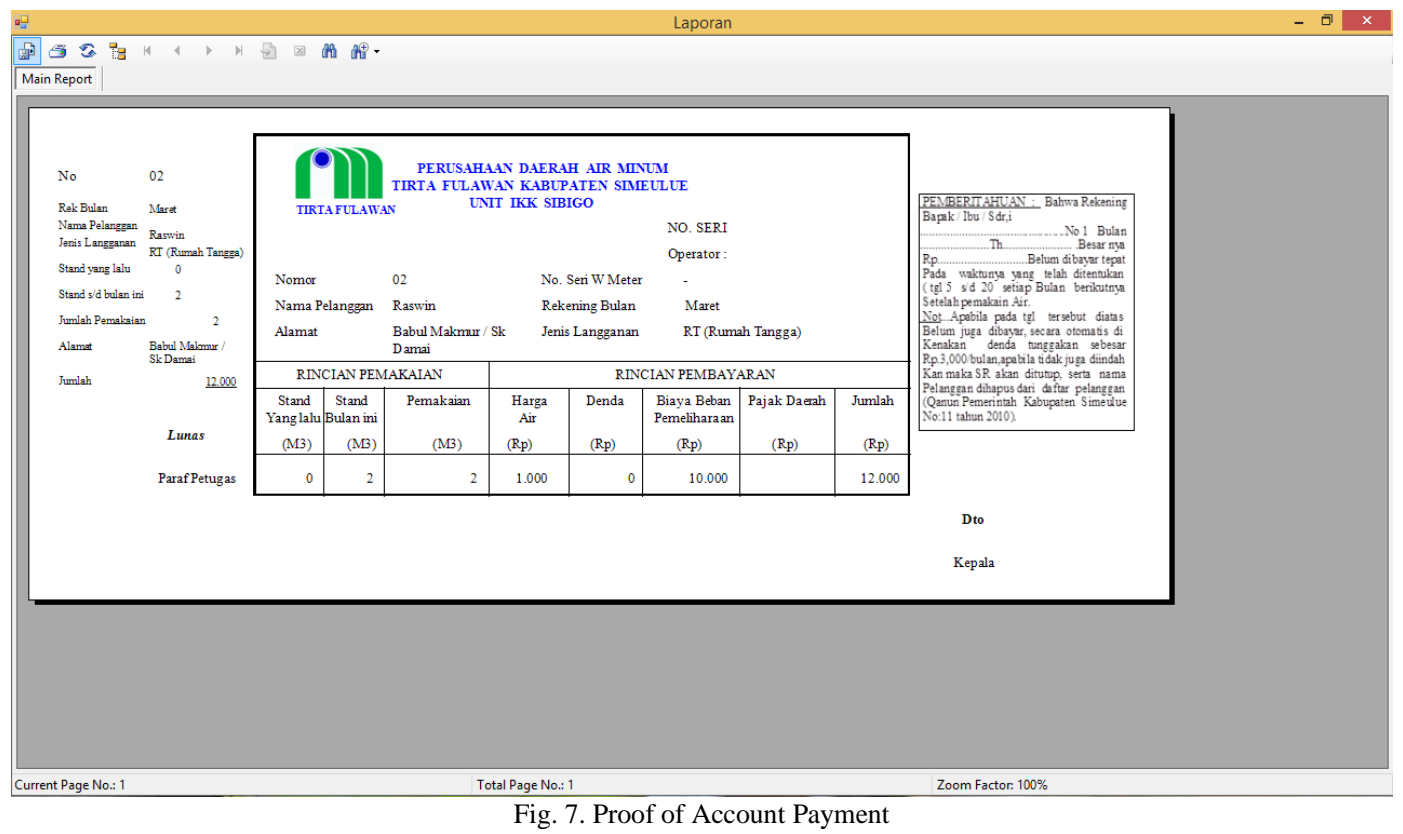

Proof of account payment is proof of payment for each customer's account, proof of payment can be printed per month or for each customer. The installation list menu is the customer master data and is the master data in this application. Previously, this data came from customer data collection.

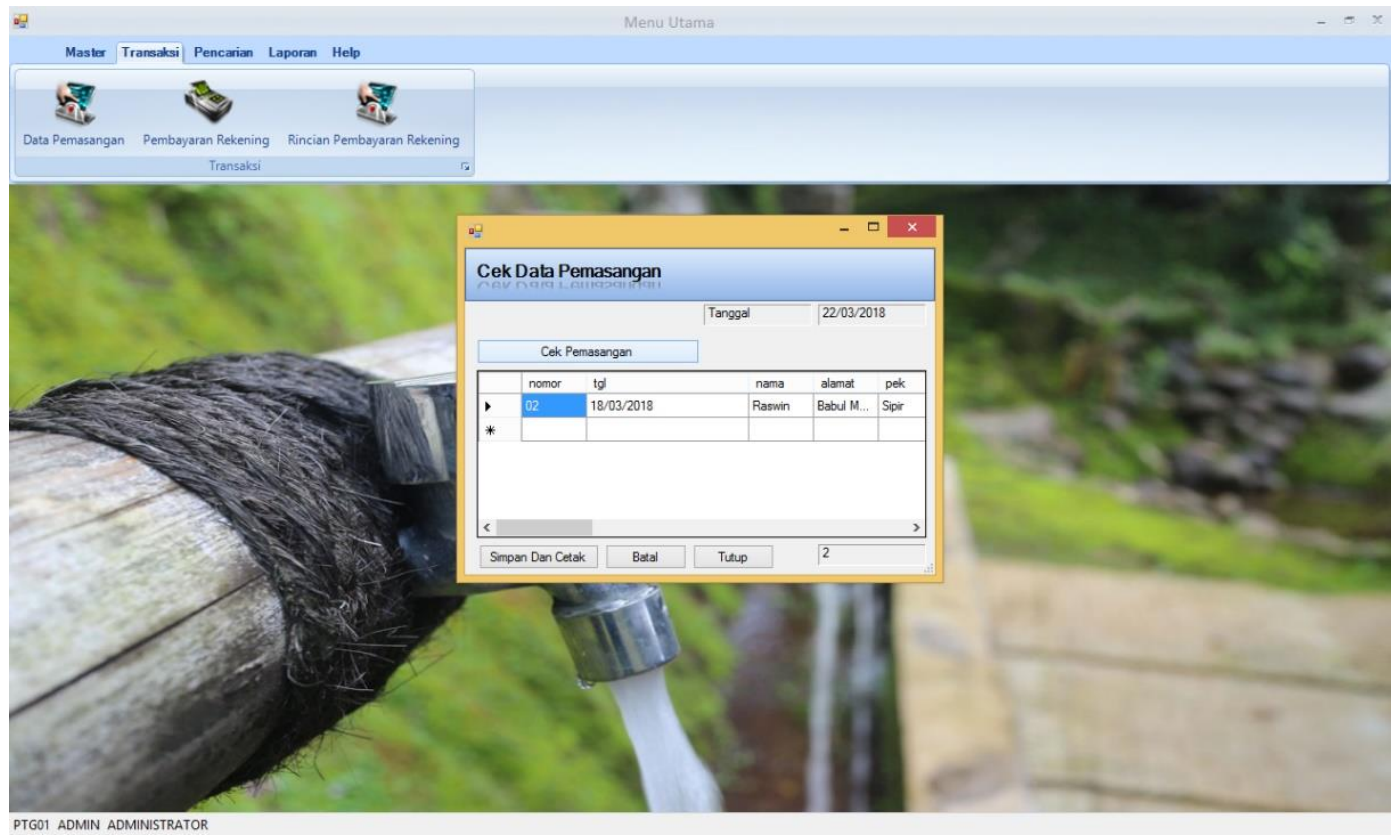

Fig. 8. Installation Data

Payment history data is information from each payment transaction recorded in the process of filling out the account payment form. 


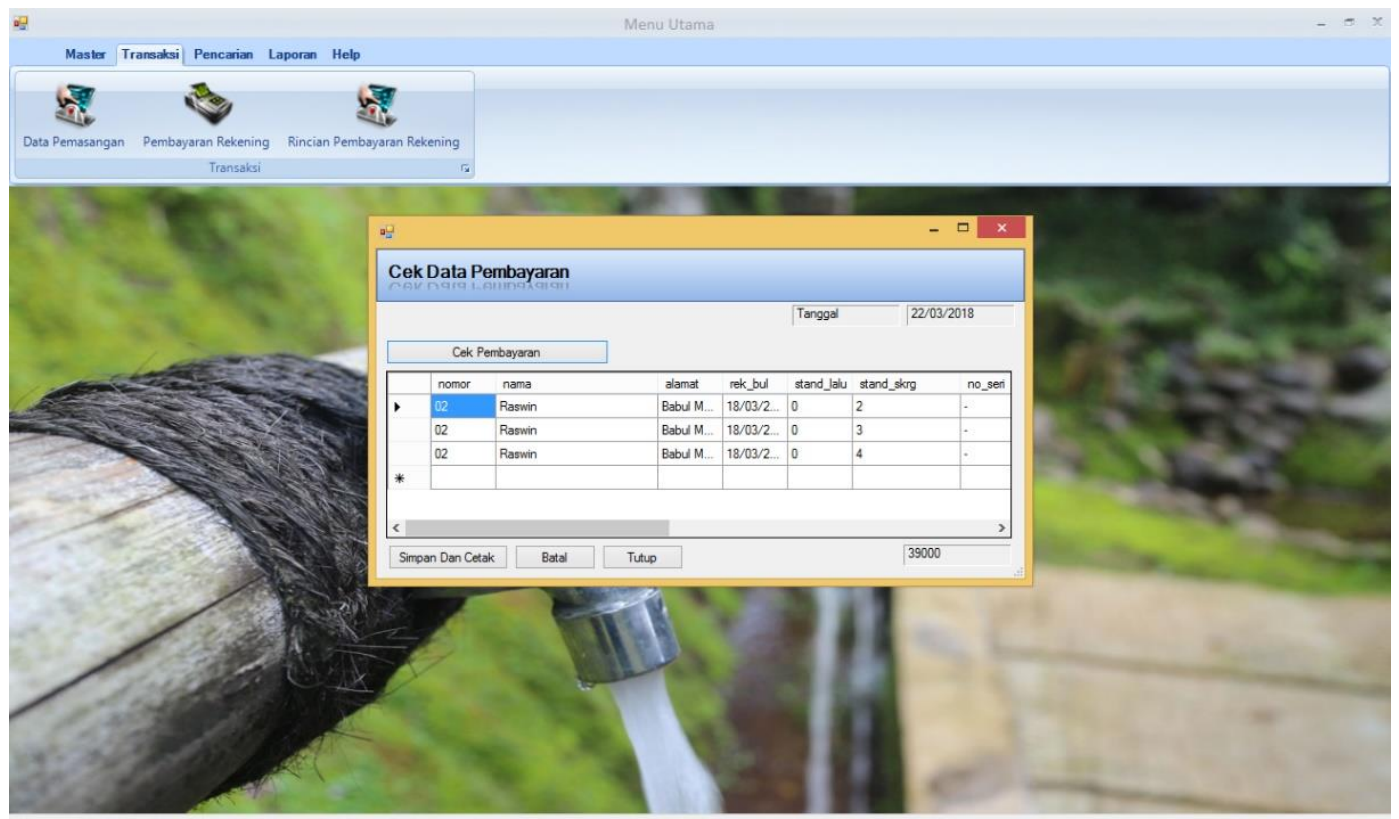

Fig. 9. Payment History Data

The search for payment details also produces the same data in the payment data but what distinguishes it is the search process that the previous form does not have.

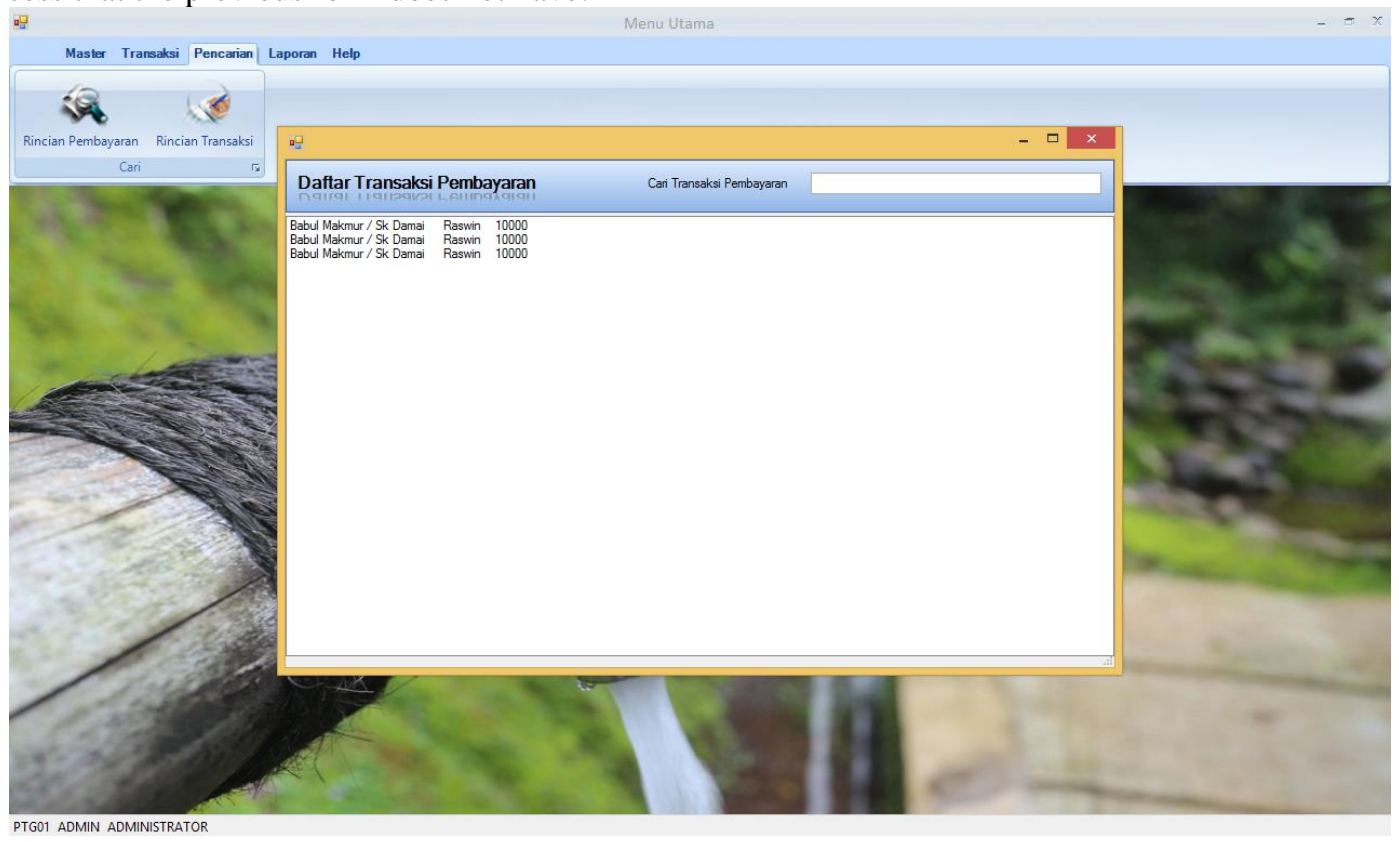

Fig. 10. Payment Details Search

The search for transaction details also produces the same data in the payment data but what distinguishes it is the search process that the previous form does not have. 


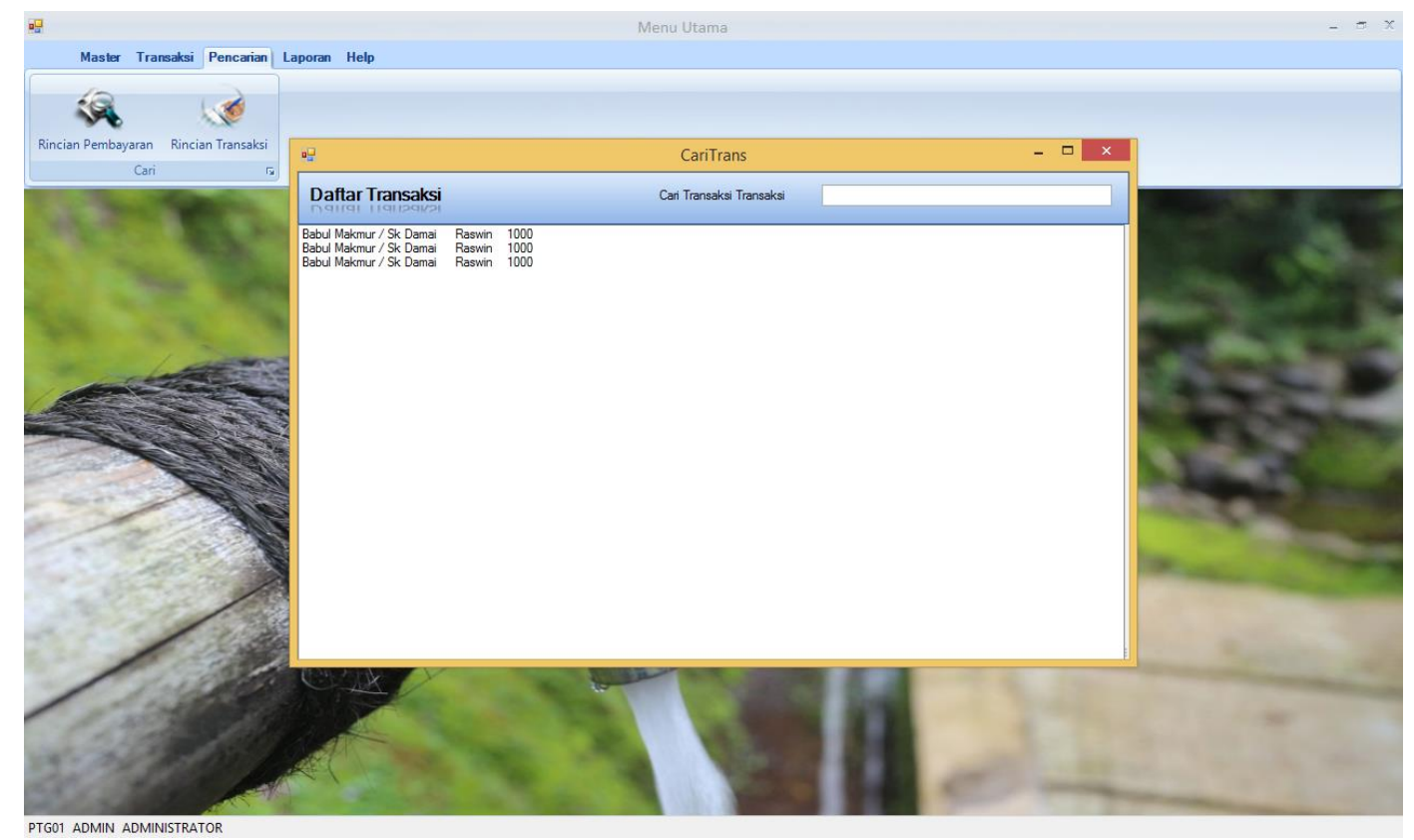

Fig. 11. Transaction Details Search List

The customer list report is a form of customer data document information containing number data, list date, name, address, occupation, serial number, type, usage, number of occupants, number of taps, paid accounts, accounts received, information, date of installation, and brand.

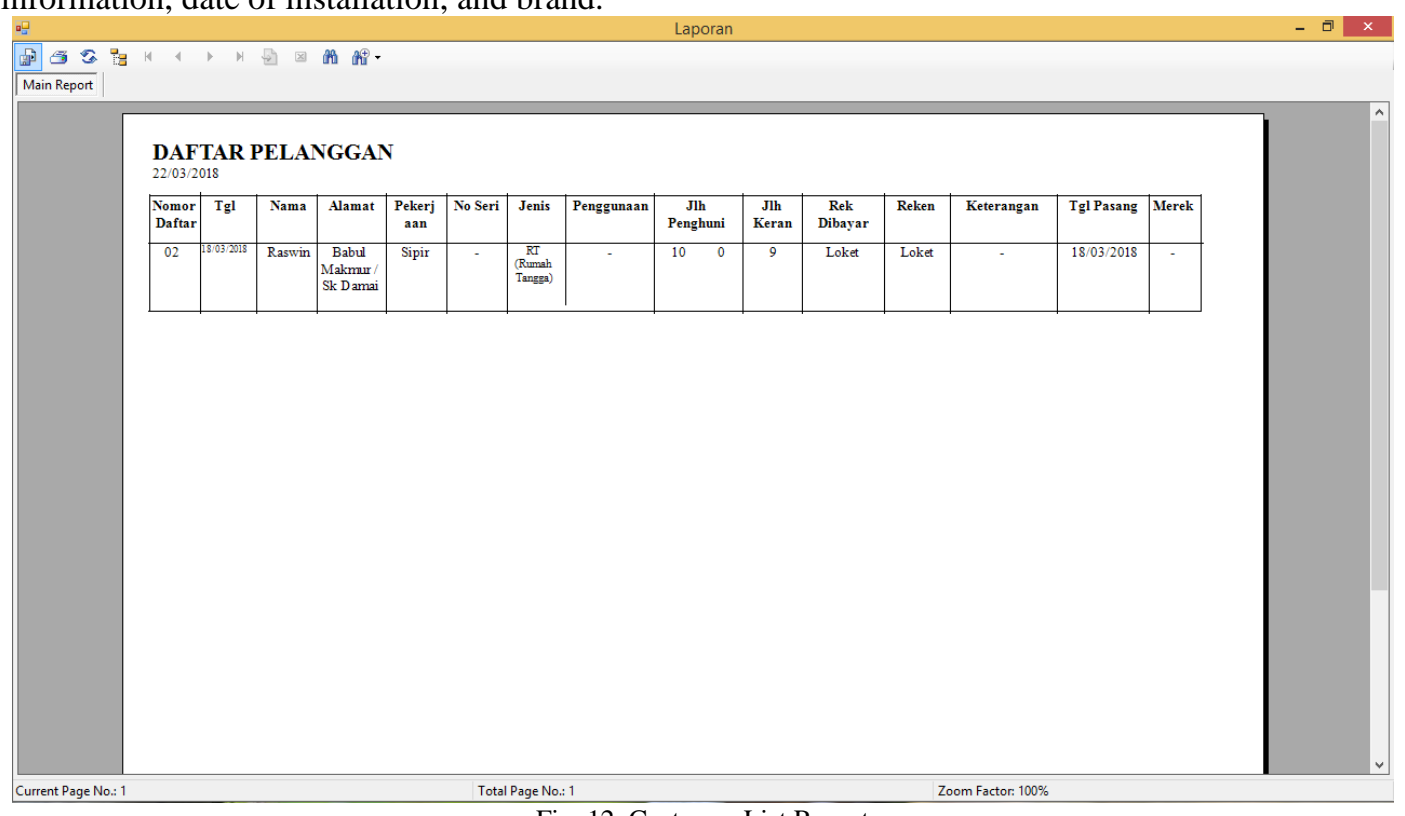

Fig. 12. Customer List Report

The customer list report menu is a form of customer data document information that contains data number, list date, name, address, occupation, serial number, type, usage, number of occupants, number of taps, paid accounts, accepted accounts, information, installation date, and brand. 


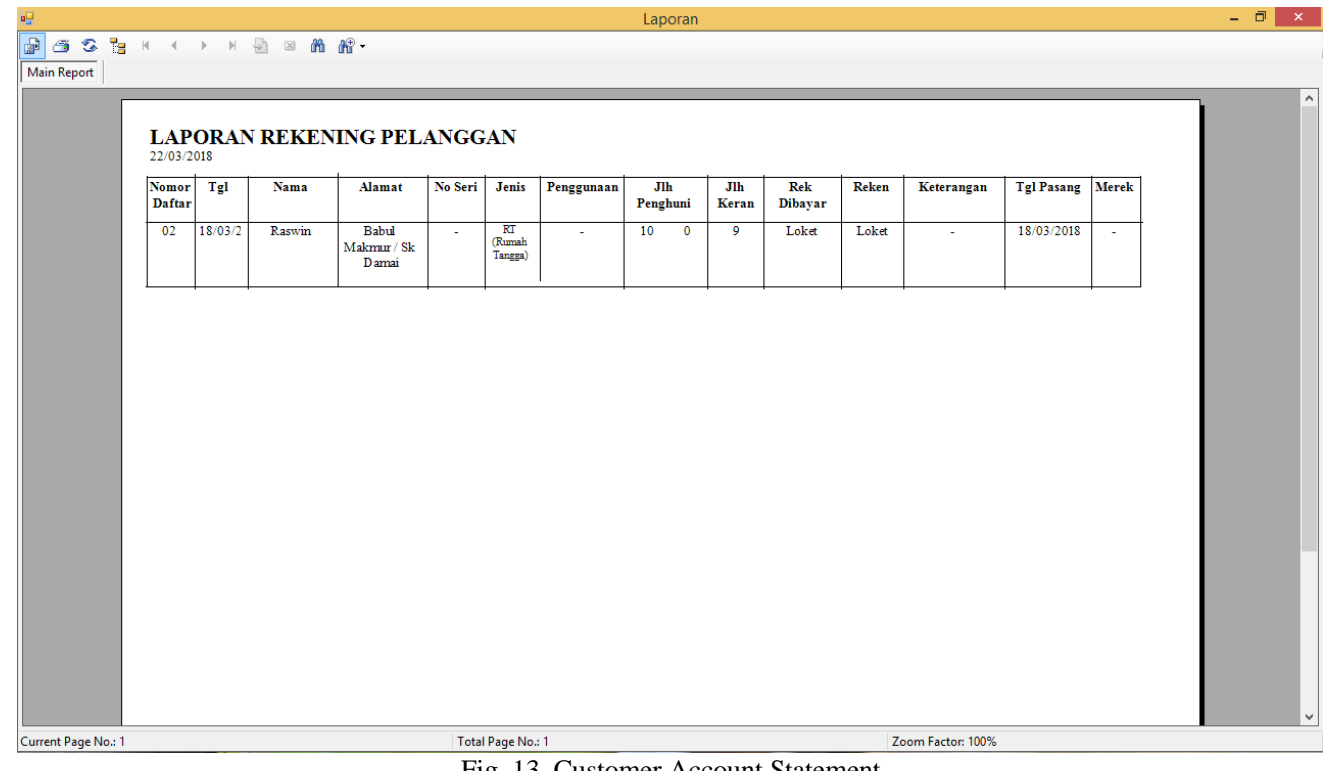

Fig. 13. Customer Account Statement

The proof of payment report menu displays the same information as printed proof of payment on the payment input form, but differences in the proof of payment report can be displayed for all proof of customer payment.

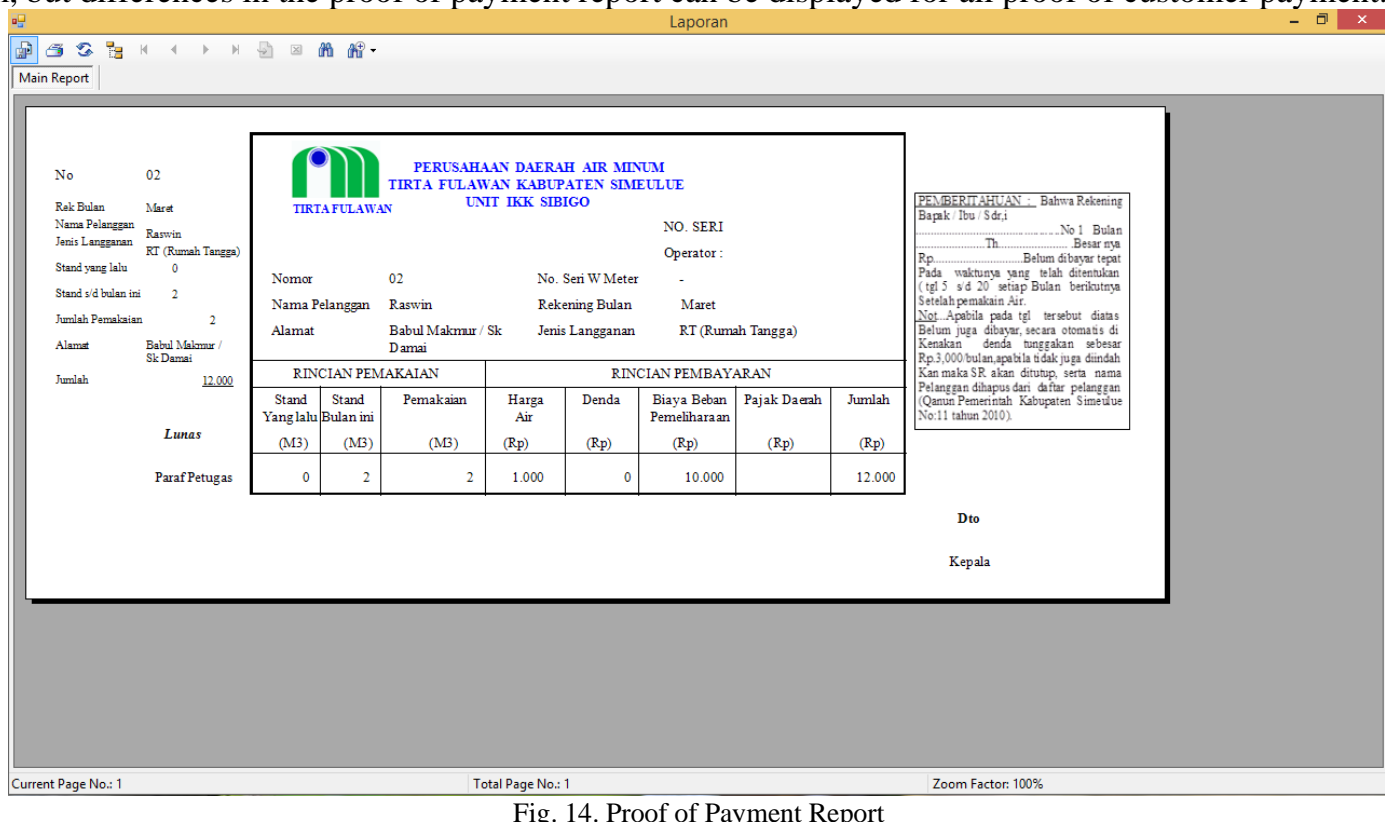

The proof of payment report is the same as in the previous payment form, but this report can print proof of payment based on the customer. The daily customer report menu is a form for printing customer data based on meter installation. This report can be printed by date, month and yearly. 


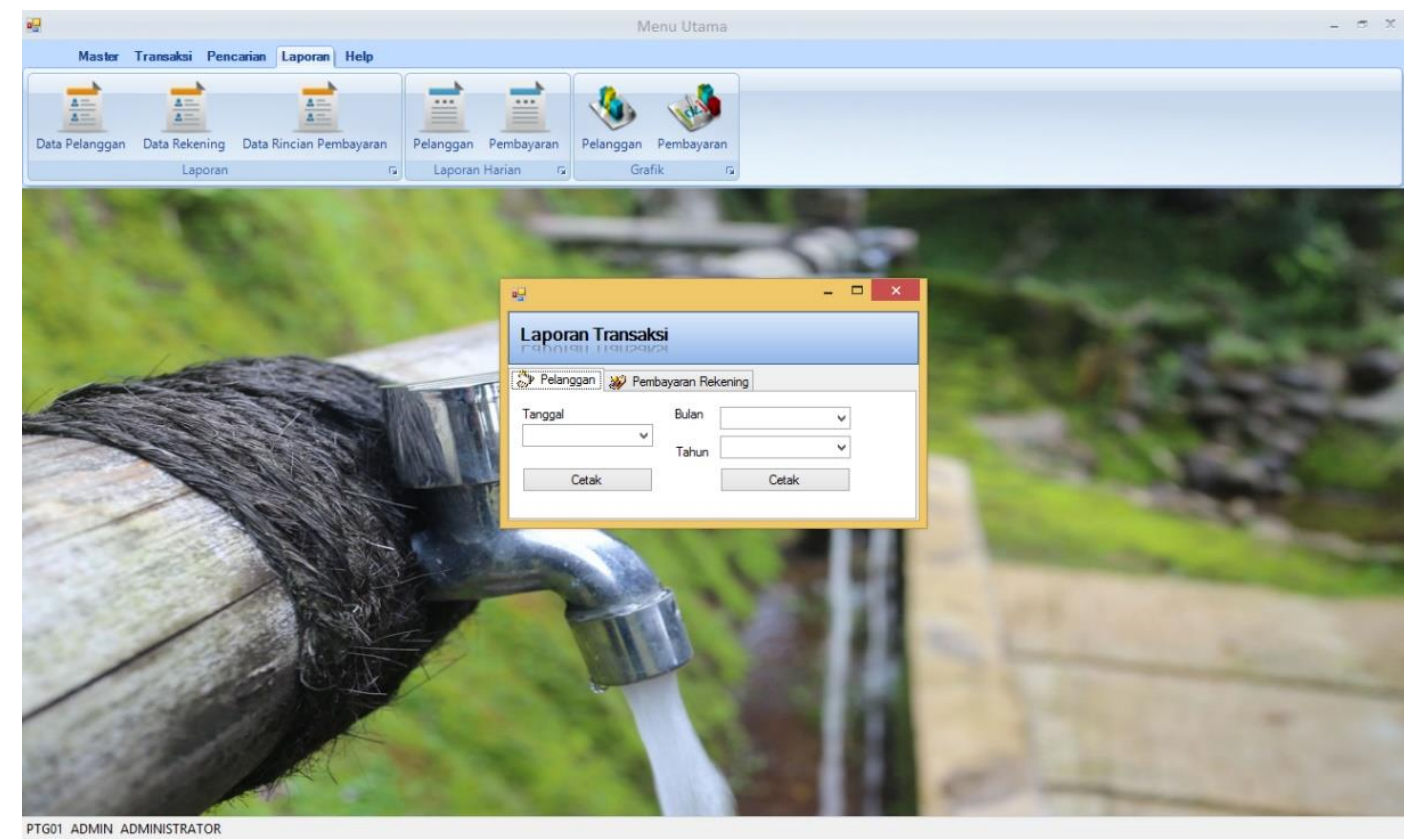

Fig. 15. Customer Daily Report Form

Customer daily reports will display data based on the customer's daily report form, this information can be displayed by selecting the month and year of the customer's account.

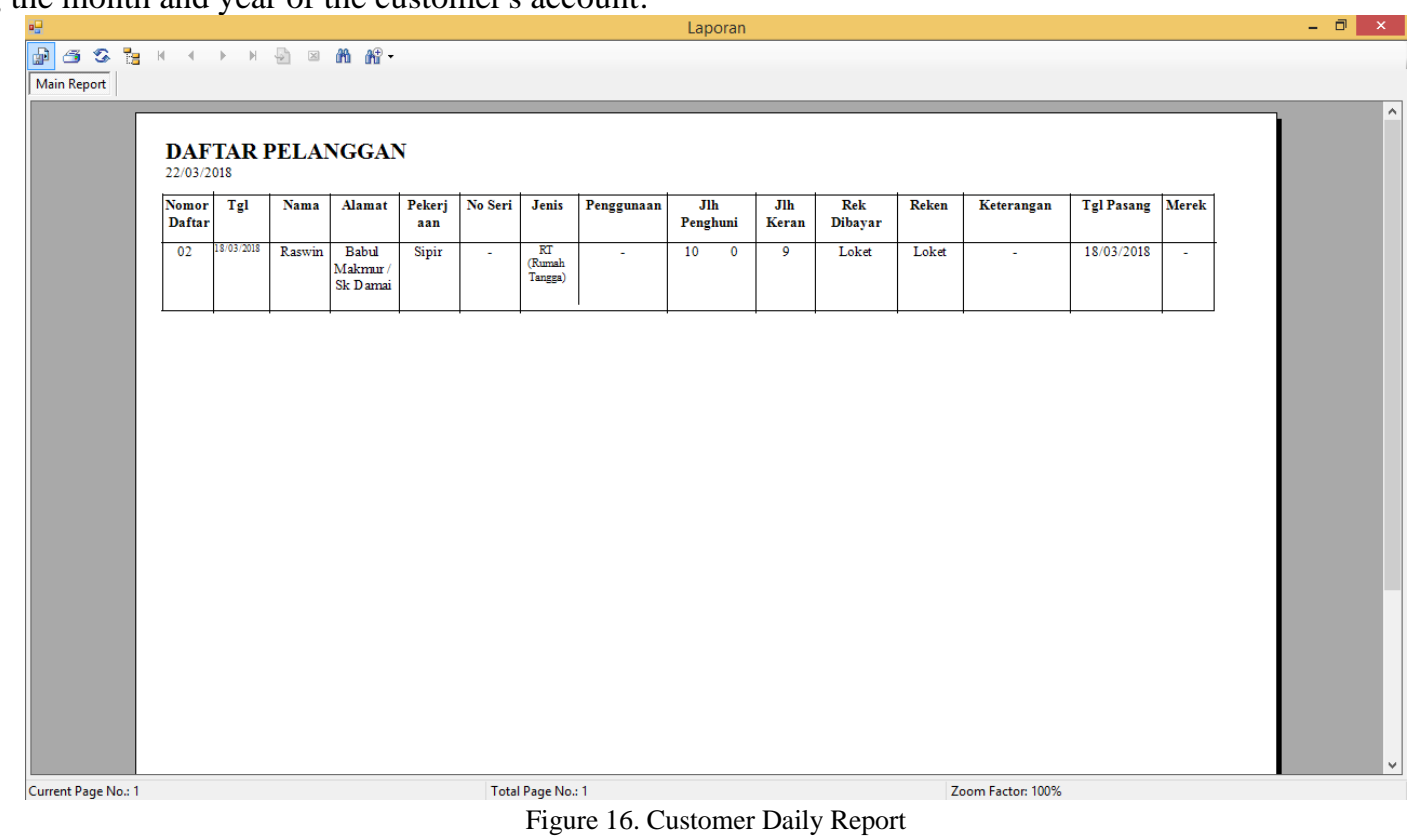

The daily payment report menu is a form for printing payment data based on transactions. This report can be printed by date, month and yearly. 


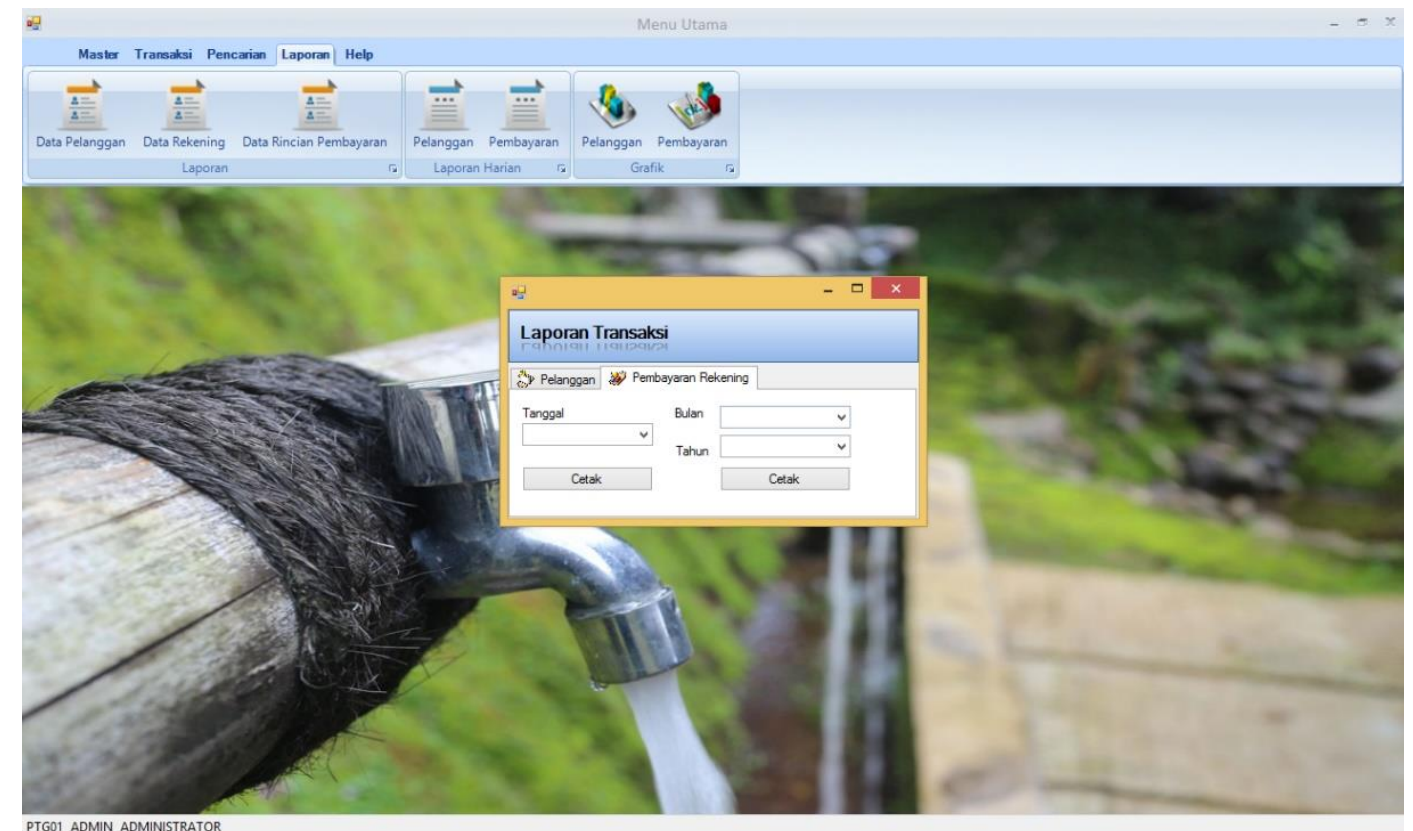

Fig. 17. Payment Transaction Daily Report Form

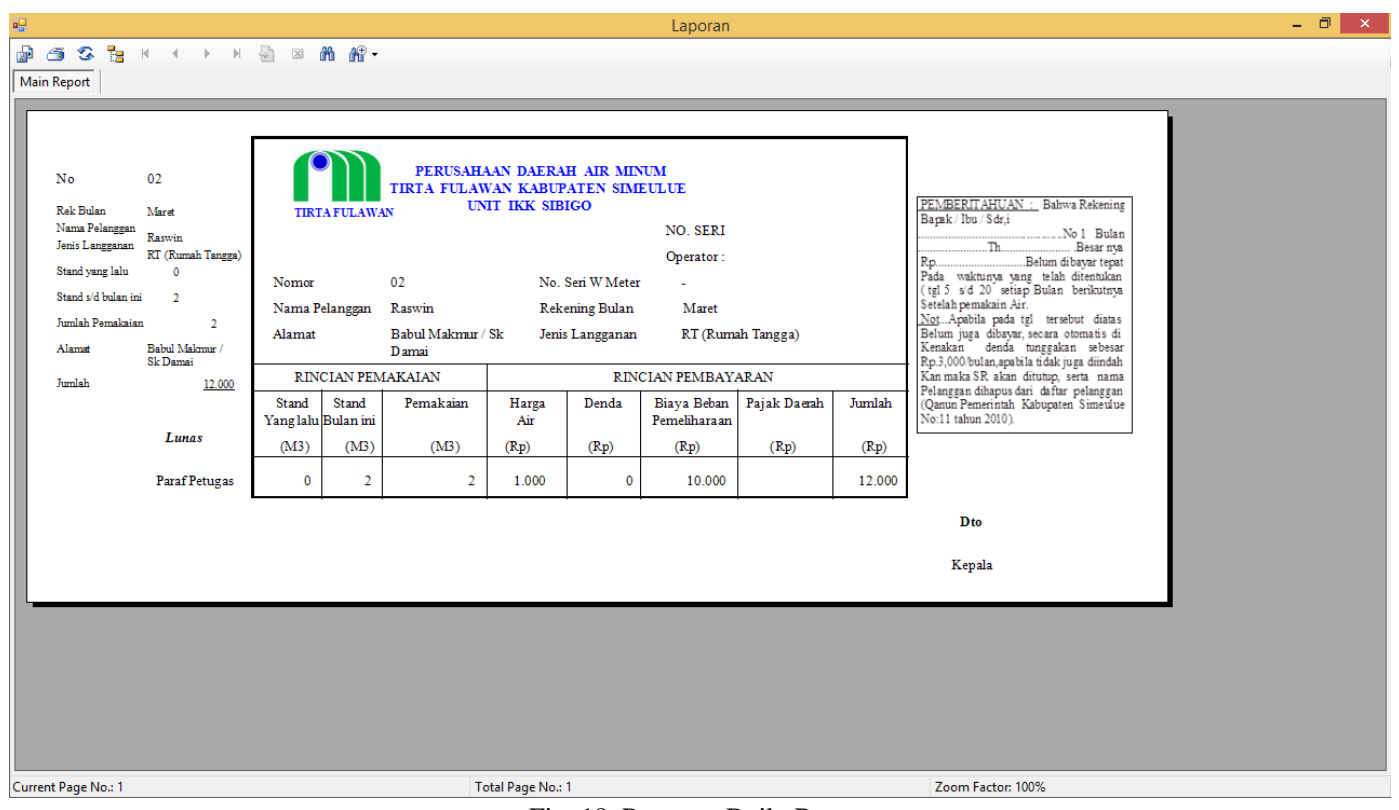

Fig. 18. Payment Daily Report

The graphic form is a page that provides the number of customers in graphical form and is displayed based on the address and transactions recorded in the system. 


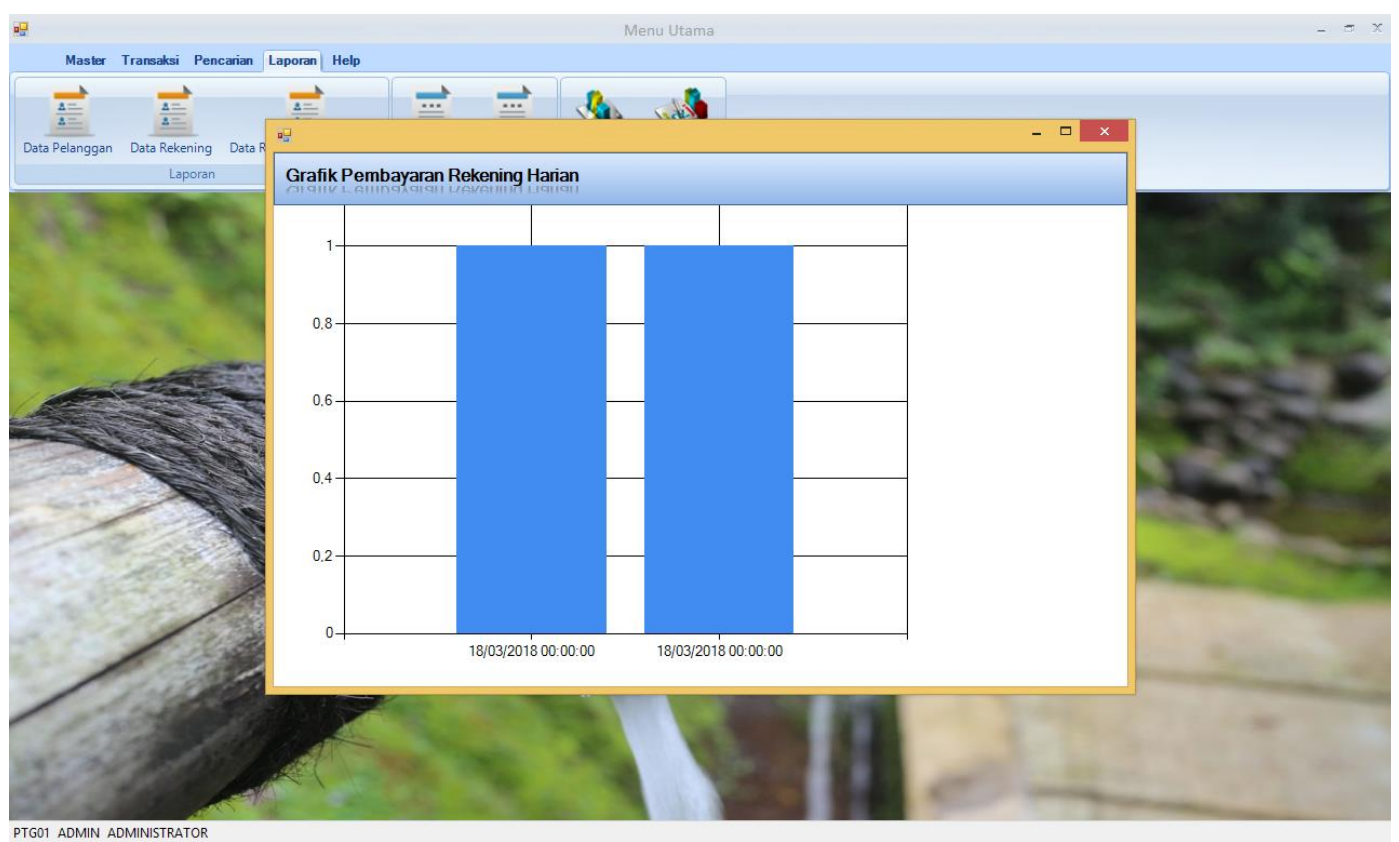

Fig. 19. Payment Graph Form

\section{Testing Method}

System testing is intended to test all software elements that are made as expected. Software testing in this study was carried out by the user or the user, while the testing method used was black-box testing [30]. Black box testing is testing the fundamental aspects of the system without paying attention to the internal logic structure of the software. This method is used to find out if the software is functioning properly. Black box testing is a method of designing test data that is based on the specifications of the software being made. The things that will be tested using the black box method are as follows:

Table 4.8 Black Box Testing

\begin{tabular}{|c|c|c|c|c|c|}
\hline No & Test Items & Test Data & Expected results & Test result & Information \\
\hline \multirow[b]{2}{*}{1} & \multirow{2}{*}{$\begin{array}{l}\text { Login by leaving the } \\
\text { username and password } \\
\text { blank }\end{array}$} & & \multirow{2}{*}{$\begin{array}{l}\text { The system will } \\
\text { refuse to log in } \\
\text { without filling in a } \\
\text { username and } \\
\text { password }\end{array}$} & \multirow{2}{*}{ 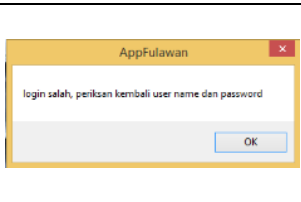 } & \multirow[b]{2}{*}{ Valid } \\
\hline & & 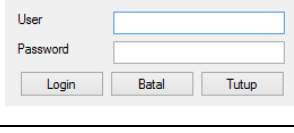 & & & \\
\hline \multirow[b]{2}{*}{2} & \multirow{2}{*}{$\begin{array}{l}\text { Login by filling in the } \\
\text { wrong username and } \\
\text { password }\end{array}$} & Login & \multirow{2}{*}{$\begin{array}{l}\text { The system will } \\
\text { refuse login and } \\
\text { then displays the } \\
\text { message ERROR: } \\
\text { Invalid username. }\end{array}$} & \multirow{2}{*}{ 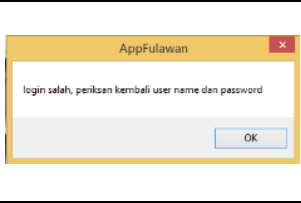 } & \multirow[b]{2}{*}{ Valid } \\
\hline & & $\begin{array}{l}\text { User } \\
\text { Pasthin } \\
\text { Password } \\
\begin{array}{|l|l|l|l|}\text { Login } & \text { Batal } & \text { Tutup } \\
\end{array}\end{array}$ & & & \\
\hline \multirow[b]{2}{*}{3} & \multirow[b]{2}{*}{$\begin{array}{l}\text { Log in with the correct } \\
\text { username and password }\end{array}$} & Login & \multirow{2}{*}{$\begin{array}{l}\text { The system will } \\
\text { receive login access } \\
\text { and redirect to the } \\
\text { main menu form }\end{array}$} & $=$ & \multirow[b]{2}{*}{ Valid } \\
\hline & & 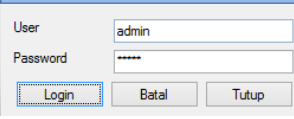 & & & \\
\hline 4 & Input user data & 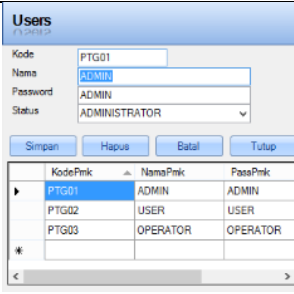 & $\begin{array}{l}\text { The system will add } \\
\text { and save the user } \\
\text { data that has been } \\
\text { inputted }\end{array}$ & 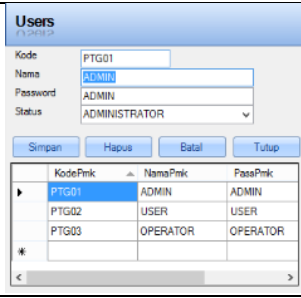 & Valid \\
\hline
\end{tabular}




\begin{tabular}{|c|c|c|c|c|c|}
\hline 5 & Input customer data & 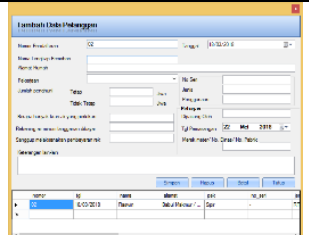 & $\begin{array}{l}\text { The system will add } \\
\text { and store the results } \\
\text { of customer data } \\
\text { that have been } \\
\text { inputted }\end{array}$ & 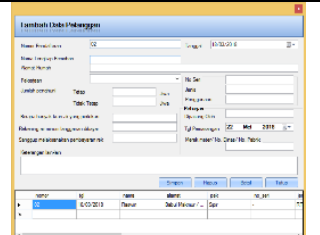 & Valid \\
\hline 6 & Enter officer data & 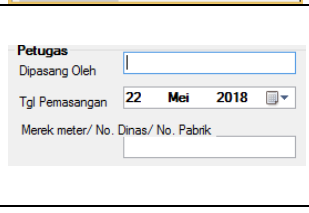 & $\begin{array}{c}\text { The system will add } \\
\text { and store the results } \\
\text { of the officer data } \\
\text { that has been } \\
\text { inputted }\end{array}$ & 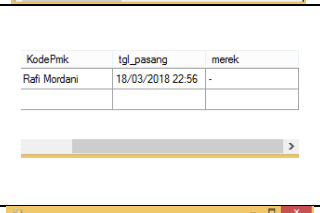 & Valid \\
\hline 7 & $\begin{array}{l}\text { Input installation } \\
\text { schedule data }\end{array}$ & 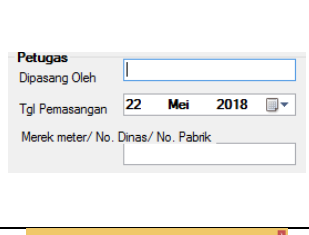 & $\begin{array}{l}\text { The system will add } \\
\text { and save the input } \\
\text { installation schedule } \\
\text { data results }\end{array}$ & 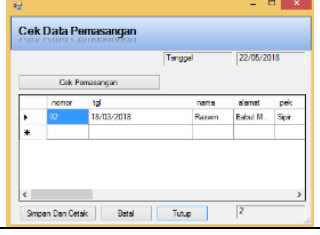 & Valid \\
\hline 8 & Account data form & $\equiv$ & $\begin{array}{l}\text { The system will } \\
\text { display the customer } \\
\text { account data form }\end{array}$ & 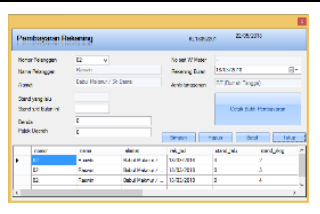 & Valid \\
\hline 9 & Payment details & ( & $\begin{array}{l}\text { The system will } \\
\text { display the payment } \\
\text { details form data }\end{array}$ & 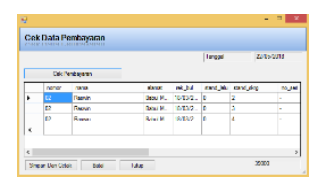 & Valid \\
\hline 10 & Customer reports & 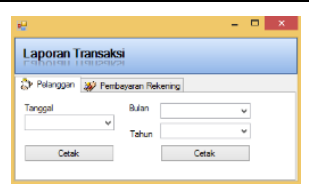 & $\begin{array}{l}\text { The system will } \\
\text { display the customer } \\
\text { report data form }\end{array}$ & 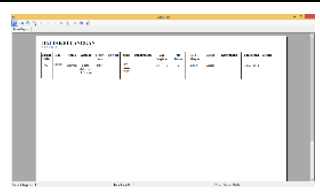 & Valid \\
\hline 11 & Account statements & 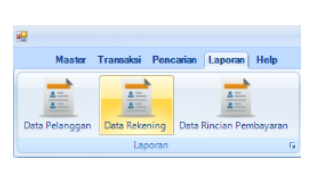 & $\begin{array}{c}\text { The system will } \\
\text { display the customer } \\
\text { account statement } \\
\text { data form }\end{array}$ & 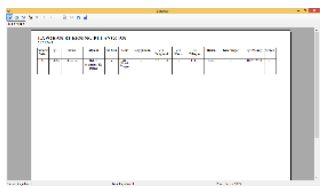 & Valid \\
\hline 12 & Payment report & 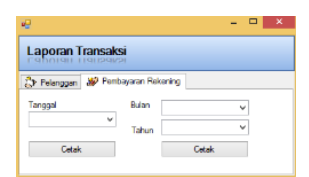 & $\begin{array}{l}\text { The system will } \\
\text { display the payment } \\
\text { report data form }\end{array}$ & 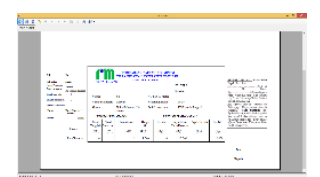 & Valid \\
\hline 13 & Chart & $\begin{array}{l}\text { Gelangan Pembayaran } \\
\text { Graik }\end{array}$ & $\begin{array}{l}\text { The system will } \\
\text { display the report } \\
\text { data form in } \\
\text { graphical form }\end{array}$ & venter & Valid \\
\hline
\end{tabular}

\section{Conclusion}

From the results of research and observations that have been carried out at PDAM Tirta Fulawan, West Simeulue District, the following conclusions can be drawn:

a) The use of customer data processing at PDAM Tirta Fulawan, West Simeulue District, information is only limited to the use of the Microsoft Excel application.

b) With this customer information system at PDAM Tirta Fulawan, West Simeulue Subdistrict, information becomes precise and accurate, especially in the service section, and to obtain information about these customers becomes easier. 
c) With this customer information system at PDAM Tirta Fulawan, West Simeulue Subdistrict, reporting information only takes 10 minutes instead of 30 minutes previously.

d) The operator of this customer information system at PDAM Tirta Fulawan, West Simeulue District, information only requires 1 person instead of relying on 3 workers.

\section{References}

[1] Nuryanto, Hery. Sejarah perkembangan teknologi informasi dan komunikasi. PT Balai Pustaka (Persero), 2012.

[2] Wali, M. "Modul Praktikum Rekayasa Perangkat Lunak." (2020).

[3] Maharsi, Sri. "Pengaruh Perkembangan Teknologi Informasi Terhadap Bidang Akuntansi Manajemen." Jurnal Akuntansi dan keuangan 2.2 (2000): 127-137.

[4] Afrina, Mira, and Ali Ibrahim. "Pengembangan Sistem Informasi SMS Gateway Dalam Meningkatkan Layanan Komunikasi Sekitar Akademika Fakultas Ilmu Komputer Unsri." Jurnal Sistem Informasi (JSI) 7.2 (2015): 852-864.

[5] Lasminiasih, Lasminiasih, et al. "Perancangan Sistem Informasi Kredit Mikro Mahasiswa Berbasis Web." Sriwijaya Journal of Information Systems 8.1 (2016): 131627.

[6] Handayani, Rini. "Analisis Faktor-Faktor yang Menentukan Fektivitas Sistem Informasi pada Organisasi Sektor Publik." Jurnal Akuntansi dan Keuangan 12.1 (2010): 26-40.

[7] Rusmawan, Uus. Teknik Penulisan Tugas Akhir dan Skripsi Pemrograman. Elex media komputindo, 2019.

[8] Machmud, Muslimin. "Tuntunan Penulisan Tugas Akhir Berdasarkan Prnsip Dasar Penelitian Ilmiah." Research Report (2016).

[9] Juliandi, Azuar, and Saprinal Manurung. Metodologi Penelitian Bisnis, Konsep dan Aplikasi: Sukses Menulis Skripsi \& Tesis Mandiri. Umsu Press, 2014.

[10] Watania, Jane Irene. "Analisis Varians Biaya Operasional Dalam Mengukur Efektivitas Pengendalian Biaya Operasional PT. Pegadaian." Jurnal EMBA: Jurnal Riset Ekonomi, Manajemen, Bisnis dan Akuntansi 1.3 (2013).

[11] Anshori, Muslich, and Sri Iswati. Metodologi penelitian kuantitatif: edisi 1. Airlangga University Press, 2019.

[12] Hermawan, Iwan. Metodologi Penelitian Pendidikan (Kualitatif, Kuantitatif dan Mixed Method). Hidayatul Quran, 2019.

[13] Simanjuntak, Mei Sunday. "Pengaruh Pendekatan Matematika Realistik Berbantu Media Digital Terhadap Kemampuan Pemecahan Masalah Matematika Peserta Didik Pada Materi Statistik Kelas XI SMA Negeri 2 Meranti TP 2018/2019." (2019).

[14] Astutik, Dwi. Pengujian Hipotesis Dua sampel Independen Berdasarkan Uji Mann-Whitney dan Uji Kolmogorov Smirnov Dua Sampel Serta Simulasinya dengan Program SPSS. Diss. Universitas Negeri Semarang, 2011.

[15] Bachri, Bachtiar S. "Meyakinkan validitas data melalui triangulasi pada penelitian kualitatif." jurnal teknologi pendidikan 10.1 (2010): 46-62.

[16] Nurdiani, Nina. "Teknik sampling snowball dalam penelitian lapangan." ComTech: Computer, Mathematics and Engineering Applications 5.2 (2014): 1110-1118.

[17] Sihite, Berta, Febriliyan Samopa, and Nisfu Asrul Sani. "Pembuatan Aplikasi 3D Viewer Mobile dengan Menggunakan Teknologi Virtual Reality (Studi Kasus: Perobekan Bendera Belanda di Hotel Majapahit)." Jurnal Teknik ITS 2.2 (2013): A397A400.

[18] Batubara, Muhammad Haris, et al. "APLIKASI PEMBELAJARAN TEKNIK MESIN OTOMOTIF KENDARAAN RINGAN DENGAN METODE COMPUTER ASSISTED INSTRUCTION (STUDI KASUS: SMK SWASTA KARYA PENDIDIK)." Informasi dan Teknologi Ilmiah (INTI) 4.3 (2017).

[19] Azwar, Saifuddin. "Asumsi-asumsi dalam inferensi statistika." Buletin Psikologi 9.1 (2000).

[20] Basuki, Agus Tri, and Nano Prawoto. "Analisis Regresi dalam Penelitian Ekonomi dan Bisnis." Depok: Raja Grafindo Persada (2016).

[21] Rahardjo, Mudjia. "Studi kasus dalam penelitian kualitatif: konsep dan prosedurnya." (2017).

[22] Basuki, Agus Tri, and Imamudin Yuliadi. "Electronic Data Processing." Yogyakarta: Danisa Media (2014). 
[23] Febriani, Nufian S., and Wayan Weda Asmara Dewi. Teori dan Praktis: Riset Komunikasi Pemasaran Terpadu. Universitas Brawijaya Press, 2018.

[24] Scheffe, Henry. The analysis of variance. Vol. 72. John Wiley \& Sons, 1999.

[25] Iversen, Gudmund R., Helmut Norpoth, and Helmut P. Norpoth. Analysis of variance. No. 1. Sage, 1987.

[26] Herlina, Vivi. Panduan praktis mengolah data kuesioner menggunakan SPSS. Elex Media Komputindo, 2019.

[27] Claessen, Koen, and John Hughes. "QuickCheck: a lightweight tool for random testing of Haskell programs." Proceedings of the fifth ACM SIGPLAN international conference on Functional programming. 2000.

[28] McHorney, Colleen A., et al. "The MOS 36-item Short-Form Health Survey (SF-36): III. Tests of data quality, scaling assumptions, and reliability across diverse patient groups." Medical care (1994): 40-66.

[29] Sternberg, Saul. "The discovery of processing stages: Extensions of Donders' method." Acta psychologica 30 (1969): $276-315$.

[30] Ismail, Ismail, and Jalisal Efendi. "Black-Box Testing: Analisis Kualitas Aplikasi Source Code Bank Programming." Jurnal JTIK (Jurnal Teknologi Informasi dan Komunikasi) 5.1 (2020): 1-6. 